\title{
SCALE AND NUMBER
}

\section{Framing an Ideology of Pastoral Plenty in Rural Mongolia}

\author{
Joseph Bristley
}

\begin{abstract}
Much recent anthropology reflects on how scales are contested and contingent products of heterogeneous social interactions, not the 'ontological givens' (sensu Carr and Lempert) described in earlier scholarship. This article examines the importance of number in the formation of scales of measurement. It does so regarding a pastoral Mongolian scale of livestock-counting based on the number ten thousand, or tüm[en]: a qualitative-cum-quantitative term suggesting plenty and abundance. Drawing on literature on the anthropology of number, and bringing it into dialogue with studies of scale and ideology, this article argues that number is not just a means for calibrating pre-existing scales. Instead, as something endowed with particular qualities and conceptual stability, number can be mobilized to produce ideologically charged scales of measurement.
\end{abstract}

Keywords: ideology, measurement, Mongolia, number, pastoralism, scale

A number of works in anthropology examine how scales are divisible into numerical or quantifiable increments. Such an approach is visible across diverse literature, ranging from analyses of how populations are governed (Foucault 1997; Mitchell 2002) to reflections on how scale making produces anthropological knowledge by yielding "sets of internal measurements and hence coordinates along which the scale of phenomena may be changed" (Strathern [1991] 2004: xvi; cf. Holbraad and Pedersen 2017). These works are situated in relation to a large body of literature produced over the last three decades, during an anthropological 'turn' to scale brought about through the writings of Marilyn Strathern ([1991] 2004, 1995), Anna Tsing (2012, 2015), and others (Carr and Lempert 2016a; Comaroff and Comaroff 2003; Gal 2016; Holbraad and Pedersen 2017; Irvine 2016; Wastell 2001). But their academic genealogy arguably runs deeper than the 1990s to include earlier twentieth-century studies of 
'spheres of exchange' (Bohannan 1959), different categories of traded valuables (Malinowski [1922] 2010), and the framing of distinct but intermeshed scales of time reckoning (Evans-Pritchard 1940).

In this article, however, I invert the basic analytic orientation of some earlier works. Instead of examining how number functions as a descriptor for calibrating pre-given scales and their increments, I show how number itself can be mobilized into scales of measurement (cf. Guyer 2004: 19). By mobilization, I mean the identification and purposeful taking up of a particular number as a quantifying element of a scale of measurement. This mobilization serves to bring into being - or 'enact'-the scale itself. I do this analytic work in relation to Mongolian ethnography surrounding the number tüm[en] and its use in a specific scale of livestock counting used to trace increases in numbers of horses. In the Khalkha Mongol dialect, and in other dialects spoken across the Mongol world, tüm[en] signifies 10,000 as an abstract quantity. It is a cardinal number that, in Mongolia's base-ten counting system, can act as a numerical referent for things and groups of things (Bazarragchaa 2005: 173). But beyond suggesting a particular quantity, it can also frame a qualitative sense of expansiveness-of plenty, abundance, and multiplicity. In this respect, it is endowed with a particularly clear sense of conceptual stability and holism. My analysis of tüm[en] in this article is ethnographically grounded in relation to a 'dörvön tümen' aduuny bayar (festival of forty thousand horses) that was held in Mongolia's Erdene soum (district) in July 2015. This festival was a muchvaunted event where local people celebrated the fact that their district was home to the most horses in the country. It was timed to be celebrated jointly with Erdene district's naadam, a national holiday celebrating important events in Mongolia's political history. ${ }^{1}$ The celebrations for the aduuny bayar, which took place over three days, framed a 'chronotope' (Bakhtin 1981) of pastoral plenty. Simultaneously an important civic occurrence and a ludic event marked by drunken exuberance, the 2015 aduuny bayar drew in hundreds of visitors to Erdene's sleepy district center from surrounding pasturelands and urban areas located farther afield.

Drawing on ethnography from the aduuny bayar and on wider views of number in Mongolia, I advance the following central theoretical argument: the number tüm[en] possesses a conceptual consistency and stability manifested in its resistance to being broken down or subdivided into smaller constituent units, and also suggests qualities of plenty and abundance. These aspects of number make tüm[en] amenable to being mobilized to enact a scale of measurement that makes ideologically important and powerfully evaluative interventions in social life. Here, this intervention is to valorize plenty in horses. My argument is thus positioned in relation to the anthropologically well-known observation that numbers function not only as abstract means of accounting, measurement, and calibration, but also as indices or symbols of diverse tropes, 
concepts, and forms of values (Crump 1990; Guyer 2004; Ross et al. 2017; Verran 2001). I build on these insights to reveal how certain qualities of number intersect with a potential for their validation and mobilization into scales of counting that can do particular ideological work. In doing so, I avoid following a Marxist conception of ideology as an instrument of mystification, used to induce a false consciousness to legitimate rule by dominant social classes (Marx and Engels [1846] 1998). Instead, my approach is more akin to that of Susan Gal (2016: 91), whose use of 'ideological' as an analytic category aims "to draw attention to the fact that frameworks of understanding constrain which aspects of social life deserve attention, which merit comparison with what, and how they are to be measured" (cf. Gellner 1978: 80; Irvine 2016). My use of ideology in this way aims to afford close attention to how large numbers and the importance of horses can be intellectualized by herders in Mongolia.

This article's argument, which describes both the social importance of horses and very large numbers in Mongolia, is developed and expanded upon across three sections. First, I begin with an ethnographic account of the 2015 aduuny bayar in which a tüm[en]-based scaling system was readily visible in articulating narratives of horse abundance. I outline the pent-up excitement readily discernable among many of Erdene's inhabitants in the days prior to the first aduuny bayar in two decades, before tracing how this event encapsulated a positive conceptual association between large numbers of horses and equine qualities in this prosperous region of central Mongolia. Second, I draw on this ethnography to examine how the number tüm[en] has come to suggest plenty and multiplicity. In Erdene district, enacting and using a scale of livestock counting based on the number tüm[en] affords both an official and popular means for reflecting upon abundance in animals in a range of circumstances: festivals, civic occasions, and paeans to local life. I also consider a range of other Mongol contexts where plenty and abundance are important and positively evaluated. These range from ideals of pastoral plenty already captured in a large body of regional ethnographic literature (Chabros 1992; Empson 2011) to less well-studied concepts of political inclusion and the proliferation of divinities in certain religions circumstances, which I explore through my own ethnographic materials. In doing so I elucidate the conceptual consistency and stability of tüm[en].

Finally, in the third section I move from this analysis of the stability of tüm[en] as an abstract idea applied to numbers of horses toward an analysis of how this number is given validation through being embedded within fixed scales deployed in celebratory contexts. I show how the fact that tüm[en] is viewed as a singularly large 'whole' number gives rise to a sense of scale that is inherently big. In this respect, tüm[en] is similar to other large numbers encountered in ethnographic and historical literature that also possess an ability to suggest qualitative plenty. ${ }^{2}$ But what makes tüm[en] ethnographically 
interesting is its ability to be multiplied into different ten thousand-based numbers (ten thousand, twenty thousand, and so forth) arranged in a series, which continue to possess a qualitative sense of plenty and abundance despite their quantitative expansion. This makes tüm[en] an ideal constituent of a scale of livestock counting that idealizes bounty in animals. In this section of the article I reflect on this fact, and on how a tüm[en]-based scale is more amenable to measuring increases in livestock numbers and idealizing plenty than other rural scales of livestock counting

\section{The Festival of Forty Thousand Horses}

Throughout early summer 2015, excitement mounted across Erdene district. A 'dörvön tümen' aduuny bayar was being held between 14 and 17 July. As my friend Bat cheerfully explained, this 'festival of forty thousand horses' would commemorate two ideologically important local milestones concerning horse abundance. First, the number of horses in this wealthy pastoral district had reached forty thousand head. Second, as was proclaimed by journalists from the capital city Ulaanbaatar covering this event for national news agencies, Erdene was officially home to the most horses of any district in Mongolia. Erdene's local government, where Bat worked before retirement, had planned celebrations of this feat since 2014. Celebratory horse races, wrestling matches, and an archery competition would be held outside Erdene's sedentary wooden soum (district) center. The population of this settlement normally empties out in summer when its inhabitants move to the surrounding countryside until autumn. But just before the first aduuny bayar in a generation, large numbers of people descended on the soum center. A sense of anticipation hung in the hot summer air as people prepared to celebrate Erdene's large horse population. Convoys of media trucks from Ulaanbaatar bounced up and down the unpaved road leading from the soum center to the games field. Herders, wearing stiff, formal deels (gowns) and carrying small traveling bags, started to arrive by motorbike or on horseback from surrounding pasturelands. After sunset, intoxicated locals and visitors from urban areas drunkenly staggered around the soum center, sharing dark streets with policemen drafted in from neighboring districts to maintain order during the festival.

On the first day of the aduuny bayar, purple thunderclouds started to gather above the games field-a large wrestling area formed through the temporary enclosure of grassland within metal railings. A few hundred meters away, traced out in black coal dust from the local Erdniin Uurkhai coal mine, lay the finishing line for the festival's horse races. While English horse races can be observed in their totality over relatively short circuits, the much great distances over which Mongol horses compete (30 to 40 kilometers) means that only the conclusions 


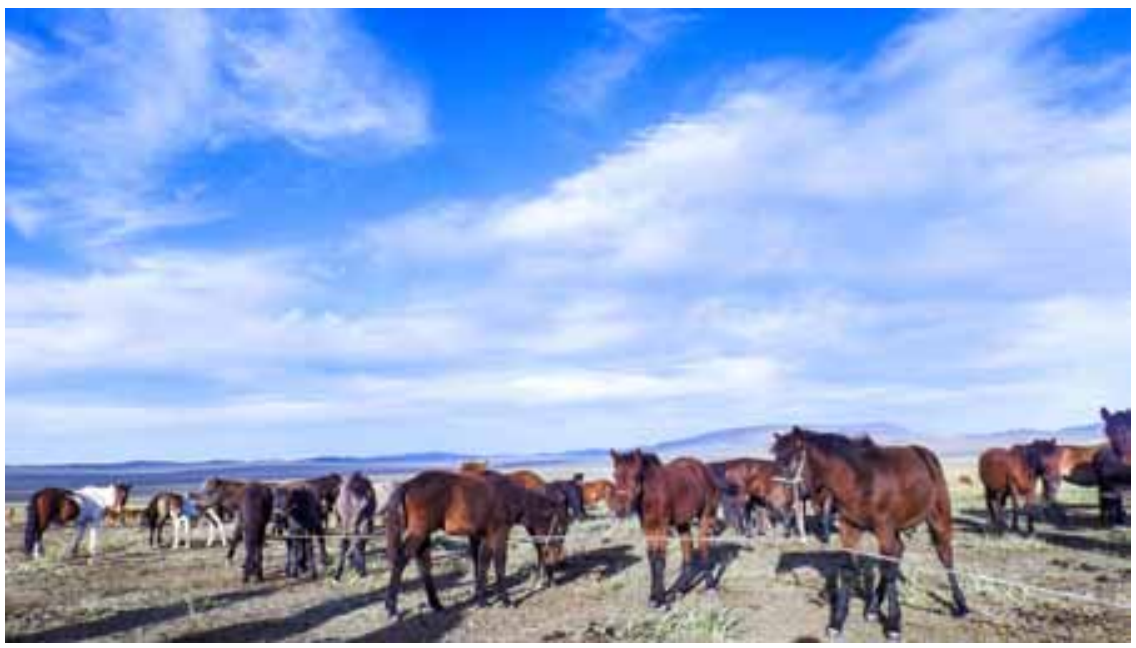

FiguRE 1: Horses in Erdene soum. Photograph ${ }^{\circledR}$ Joseph Bristley

of races can be seen by on-the-ground spectators. At the 2015 aduuny bayar, it seemed fitting that abundance in horse numbers would be celebrated through horse races involving dozens of competing mounts and riders. Over the course of the festival, six horse races would be held: for daaga (two-year-olds), shüdlen (three-year-olds), khyazaalan (four-year-olds), soyoolon (five-year-olds), ikh nas (six-year-olds plus), and azarga (stallions). Producing speed through the intersection of rider and mount (Virillio [1977] 2006: 108-109), the trainerowner of a prize racehorse can win prestige and prize money or goods, for example, fine Erdenet wool carpets or a box refrigerator. The schedules for these races were displayed on big banners near the finishing line. Dinners, speeches, and meetings designed to 'honor' this event were meticulously timetabled under a large slogan heralding the "Programme for the Ninety-Fourth Anniversary of the People's Revolution, and the Games Celebrating Erdene District's Festival of Forty Thousand Horses." The banners made bold written references to a form of horse abundance otherwise more crudely 'legible' in the big horse herds dotted across Erdene's steppe (cf. High 2017). The same displays also announced that the first evening of the festival would feature a musical concert in the local Culture Center to "honor the festival of forty thousand horses." Other events included a special meeting of local citizens, a dinner, and speeches by local politicians lauding the success of Erdene in raising so many horses in its pasturelands.

Plenty in horses has long been important in Erdene. This is reflected in local historiographical traditions that emphasize an abundance of horses based on data stretching back to the 1910s. Thus, D. Sürenkhorloo (2010: 19), a local 
historian of Erdene soum, notes that in the early twentieth century his home area was "the richest district of Daiching Wang khoshuu" (the previous administrative unit covering today's Erdene soum). Copies of D. Sürenkhorloo's book on Erdene's local history, which emphasizes the area's qualities as a region with plentiful horses, can be found in most households in the soum. Early in our friendship, Bat had given me a copy of this book "to help with my research." As D. Sürenkhorloo went on to say, "in 1918, around 80,000 head of livestock were registered [in Daiching Wang khoshuu]" (ibid.). These numbers were, by Mongolian standards, large indeed. In 1924, one of Erdene's two Buddhist monasteries was wealthy enough to donate the huge sum of 500 'high quality horses' (shildeg aduu) to the new People's Government to fund the development of Mongolian civil aviation (ibid.: 172). Between the time of this donation and early 1990, Mongolia was a socialist People's Republic with a planned economy aimed at the expansion of industrial and agricultural production (Bawden 1968). The demise of state socialism in the early 1990s resulted in livestock being disembedded from the ownership of the local Oktyabryn Tuyaa Negdel (Light of October Collective) and vested in private hands (cf. Humphrey and Sneath 1999; Rossabi 2005; Sneath 2012). The rapid post-1990 expansion of a subsistence 'domestic mode of production' (sensu Sahlins 1974) was accompanied by significant increases in Erdene's livestock population, including horses.

In today's Erdene, as Bat revealed, an ideology of plenty in horses is framed in relation to two referents. Large numbers of horses within households are instrumentally appreciated for having relatively high exchange values. ${ }^{3}$ Horses are also intrinsically valued as animals endowed with a range of 'qualities' (chanar) that make them exemplary among other herd animals. In this respect, horses are regarded as particularly 'strong' (khüchtei), and their physical prowess is considered analogous to that of tigers (cf. Empson 2011: 245). These qualities of horses intersect with a particular form of respect given to them by humans. As Bat said, they "are the most highly honored and sanctified [khamgiin ikh deedelj shütne] of all livestock." These are feelings of high esteem. But they are capable of even greater emotional amplification and lyrical development in tsol duudakh (praise songs) chanted in honor of prize-winning racehorses. A typical tsol lauds the winner (türüü mor') of a summer horse race in this way:

At the end of this peaceful and fortunate day,

On the day of the great summer games,

From the horse placed first in the race,

Come forth ten thousand [tümen] offspring and a flock of one million foals!

You who run like the wind,

You who raise dust as you run,

You whose hooves strike the ground like hail,

You, who are praised in this song for your steady finish to the race.

(see Chingel 1990: 374-375) 
For the anonymous author of this tsol, the use of number ("ten thousand" and "one million") appears in the context of a benediction. Plentiful progeny are called down on a winning racehorse. Wider Mongol perspectives on pastoral abundance (Chabros 1992; Empson 2011), which are typically manifested in the plentiful production of progeny, can thus be reflected upon through a quantitative lens. Like the author of the $t s o l$, Bat found it difficult to conceptually disentangle an appreciation for horses and their qualities from a positive ideological reflection on their existing in large numbers. In one sense, his approach was that of a local person (nutgyn uuguul) proud of his home area's record in horse rearing. In a second sense, his view was that of a retired local official-a successful and respected politician who strove to improve the quality of Erdene's pastoral system in the politically difficult circumstances of the privatization era of the early 1990s. From a third point of view, his perspective was that of a man with a unique ability to treat horses when they fall ill through bloodletting with a sharpened piece of deer antler. From all these perspectival positions, plenty in horses was something worth celebrating in itself as an almost existentially important issue. In this respect, Bat's comments call to mind observations made in classic anthropological studies of pastoralism, where ethnography reveals the importance of concepts of plenty in how people think about and utilize their livestock (Evans-Pritchard 1940; Lienhardt 1961). Reflecting on the number of horses in Erdene, Bat stated: "Our soum is, in essence, horse country. We love horses. The grass and other forms of vegetation make the area suitable for pasturing horses." As I now show, tüm[en] is well-suited to quantify abundance in horses in Erdene.

\section{The Conceptual Stability of Number}

The day after the aduuny bayar ended, when life in Erdene started to resume its usual quiet pace, I visited Bat's home on the hill overlooking the soum center. As he poured me a bowl of salted milk tea from a teapot kept by the foot of a blackened iron stove, he mused on the remarkably large size of Erdene's collective horse herds. As I drank my tea, I asked why exactly people in Erdene celebrated when horse numbers rose by 10,000 head. As Bat pointed out, and as was emphasized during the festival via banners, announcements, and spoken praises from local officials, tüm[en] is a very large number indeed. Erdene's herders are regularly confronted with 10,000 as an abstract quantity in their daily economic lives. The most commonly used word for ten thousand in Mongolian is arvan myanga[n]. While tüm[en] refers to a singe unit of ten thousand, arvan myanga[n] suggests 10,000 as a number composed of ten units of one thousand. The latter is used, for example, to refer to units of currency. In the early 1990s, Mongolia's economy experienced incredibly high levels of 
inflation: "The general consumer price index rose 54.3 per cent in 1991, accelerated by 321.1 per cent in 1992 and rose by a further 193 per cent in 1993" (Griffin 1995: 4). This led to a proliferation of high-denomination bank notes. Currently, inflation rates run at a much lower level (forecast at 8.5 percent for 2019) (cf. Asian Development Bank 2019). Nevertheless, Mongolia's small units of currency have effectively dropped out of circulation (Bristley 2015: 36), and very large numbers continue to calibrate the highest-value bank notes. ${ }^{4}$ At the time of the 2015 aduuny bayar, for example, one MNT 10,000 bank note could purchase approximately one $70 \mathrm{cl}$ bottle of Ulaanbaatar vodka, four large bricks of pressed black tea, or five liters of petrol from soum center establishments. But despite herders' familiarity with 10,000 as an abstract unit quantifying currency, such large figures are never encountered through phenomenal engagement with their own flocks. The largest herds in Erdene are up to two thousand head in size, and single individuals could not possibly accumulate ten thousand head of livestock themselves. Historically, such large herds have been collected primarily through coercion and appropriation (Bawden 1968: 397-398; Sanjdorj 1980), rather than as the outcome of individual or household labor. ${ }^{5}$

But although arvan myanga[n] suggests quantitative largeness, this number is not endowed with the conceptual holism, fixity, and intellectual consistency of tüm[en]. In relation to the 2015 aduuny bayar, this consistency was manifested in a way that was both literally quantitative (forty thousand horses were carefully enumerated in Erdene before the 2015 aduuny bayar) and figuratively qualitative (the use of tüm[en] in the aduuny bayar was deliberately designed to evoke ideas of plenty). In a general sense, tüm[en] affords a sensation of plenty, abundance, and multiplicity. In terms of its qualitative-cum-quantitative endowment, tüm[en] shares some features of what Jane Guyer (2004) refers to as 'tropic numbers'. Reflecting on counting systems as they are used in West African economic contexts, Guyer observes that certain numbers index specific qualities. As she notes, they go beyond being mere instruments of abstract quantification and instead come to act as "potential referents across the registers, to words, things, bodily kinetic and spiritual powers” (ibid.: 66). Tüm[en] does not refer to somatic or spiritual registers like some Yoruba numbers. However, it stretches between different registers of social life to suggest abundance and multiplicity. Importantly, tüm [en] does so in a way that allows an ideologically powerful scale of measurement to be enacted. This was clear in the context of the aduuny bayar, when Bat mused on Erdene's large horse herds. But it is also evident in other contexts. Thus, Fr. Antoine Mostaert ([1941-1944] 2009: 686), the Roman Catholic missionary and scholar of early-twentieth-century Inner Mongolia, defined one meaning of tüm[en] in the Ordos region as "multitude, the whole world" (cf. Dulam and Vacek [1983] 2013: 135-136; Tumurtogoo 2018: 258). Today, meanings of tüm[en] among Erdene's dominant ethnic group, the Khalkha, are similarly expansive. In political discourse, the compound ard 
tümen refers to 'the people' as a multiplicity of engaged citizens united through a single political agency (cf. Humphrey 1992: 376). ${ }^{6}$ It is suggestive of the term 'masses', put to use in the political philosophy of Vladimir Lenin ([1918] 1992), which was absorbed into Mongolian political thought from the 1920s onward. Bat, who worked for 16 years in local government, used this term frequently to describe the citizens of Erdene, whether in the context of pasturing rights for herders, district elections, or notions of local identity. Tüm[en] has a similarly expansive connotation in Buddhist liturgies periodically performed in Erdene's monasteries and homes. The well-known "Dünchüür Maan'," a litany of saints and gods chanted for the souls of the dead, invokes "ten thousand heavenly Bodhissatvas/and ten thousand Buddhas” (negen tümen Khon'som Bod'sadva/ negen tümen Burkhan ba). ${ }^{7}$ In this context, tüm[en] evokes an ever-escalating series of expansions of divinity positioned between one hundred and one hundred million. Here, quantity glosses the qualitatively expansive nature of powerful beings that can help the dead achieve a good rebirth.

The second way in which tüm[en] is endowed with a sense of holism is in a more abstract, quantitatively framed sense. As a number, tüm[en] could theoretically be disaggregated into its constituent units. Mongolian writings on the subject show it as just one number among many (Bazarragchaa 2005: 173-174), implicitly capable of addition, multiplication, subtraction, and division. It sits in a series of numbers ranging from 'neg[en]' ('one') all the way to numerical infinity. But the logic of partibility that forms part of a standard assumption about ordinal numbers in Mongolia was not reflected at Erdene's 2015 aduuny bayar. For Bat and others in Erdene, the idea of a 'part-tüm[en]' or 'half-tüm[en]' would be nonsensical. Instead, the number was uncritically regarded as a whole number, albeit one that was ultimately achieved through the tallying up of all the horses herded across Erdene. This gave it an irreducible feel, meaning that once one or more tüm[en] of horses had been counted, this number could be valorized as something inherently big and conceptually appreciable in its own terms. Hence the fact that the 2015 aduuny bayar was held in the first place.

\section{Enacting Scale}

If tüm[en] possesses consistency as an abstract idea applied to livestock numbers, it is given validation within a scale of livestock counting that is affectively powerful, emotionally compelling, and ideologically important for many of Erdene's inhabitants. As I continued to ask Bat about the relationship between Erdene's collective horse herd reaching forty thousand head and the rationale for holding a festival to celebrate such an event, he paused for thought, surprised to have to justify such an obvious state of affairs. Folding his brows, he 
provided an answer that correlated the importance of a discrete, conceptually stable number (tüm[en]) with the importance of organizing a festival to celebrate that number being reached. The link between these two factors, he said enigmatically after pouring another bowl of tea and replacing the pot by the stove, was mandated by "the rules." As he went on to explain: "We Mongols celebrate when livestock numbers reach one-tümen head. These are the rules [juram]!” In Mongolian, juram refers to general legal or procedural principles typically specifying rights, obligations, and duties. But the juram Bat mentioned were not rules in any formal legal sense. Their invocation was primarily intended to describe appropriate behavior in a context where doing things in a 'correct' (zöv) or 'proper' manner is seen by many to be important (cf. Empson 2011: 98-99; Humphrey 1992). While Bat's explanation discursively focused on 'rules', its underlying conceptual focus was on people's behavior and the possibility of their evaluating this behavior (cf. Firth [1953] 1964: 208-209; Graeber 2001).

When Bat spoke of 'the rules' mandating the timing of aduuny bayar festivals, he primarily referred to the importance of holding a celebration to mark large-scale increases in horse numbers. But he also suggested the official nature of the whole exercise. That is to say, the mobilization of tüm[en] as an ideologically powerful scale of measuring livestock numbers involved a decision having been made for it to be used in this way. From an analytic perspective, this point may seem to advance a tautology, but this is not so. The use of scale, as E. Summerson Carr and Michael Lempert (2016a) note, is never neutral. Instead, it is inherently perspectival and saturated with meaning (Irving 2016). In the context of the 2015 festival, the enactment of tüm[en] as a scale of counting was less a conscious choice by any individual and more the outcome of the widespread recognition of the evaluative force of this number. It represented the deployment of tüm[en] as a term that is both well-known and readily intelligible to many local people. It underpinned the theme of the entire aduuny bayar, which was organized by a special commission (komiss) consisting of local officials. The komiss was responsible for everything: the issuing of invitations to important visitors; the organization of prizes for winning racehorse owners; and the spatial layout of the festival site, from the finishing line of the race course to the location of 'hospitality' yurts offering free vodka and food to visitors. The komiss' recognition of a 'dörvön tümen' aduuny bayar as something worth celebrating went beyond the deployment of tüm[en] as a number that just quantified plenty in horses. It was also concerned with the mobilization of number into a scale articulating how that plenty could be measured. This work had a diachronic dimension that went beyond a simple process of enumeration. This is because the 2015 aduuny bayar was not the first one celebrated in the district. It was, in fact, the fourth. The first aduuny bayar, for ten thousand horses, was held in 1977. A second festival, held when the number of Erdene's horses increased to 
twenty thousand head, was held in 1992. When the total horse herd of Erdene reached thirty thousand head in 1999, a third festival was held to celebrate. Bat suggested that a 'dörvön tümen' aduuny bayar would have been held before 2015, were it not for a series of cold winters in the early 2000s that resulted in a significant and disproportionate reduction in the total number of the district's bod mal or big livestock (horses and cattle) (cf. Sneath 2012).

As a means to gloss abundance in horses, a tüm[en]-based scaling system presents an ideologically more powerful view than other local systems of livestock counting ever could. This can be observed in its being the preferred means of accentuating abundance in horses over other scales of counting more familiarly encountered in pastoral life. Alongside the special tüm[en]-based system of counting, which traces the growth in Erdene's horse population from ten thousand in 1977 to forty thousand in 2015, a standard counting scale based on the number one exists in Erdene. This is the most commonly encountered scale of counting in the area. It is used in livestock count-ups during herders' phenomenal engagement with their flocks on an almost daily basis, and as a basic means of calibrating numbers of livestock in official livestock censuses. Official numbers of Erdene's livestock, dating back to shortly after the foundation of Erdene district in 1938, are presented on a large board in Erdene's ramshackle district museum. These figures, which actually show significant fluctuations in the local horse population, ${ }^{8}$ were presented at the museum to reveal overall 'growth' (ösölt) in the area's number of horses (and other livestock). They had been arranged in a graph to form a 'time-map' (Gell 1992) of animal productivity from the time of the district's earliest censuses to the early 2000s, albeit across high levels of fluctuation. The purpose of such 'maps', as Alfred Gell summarized spatialized temporal representations including time charts and other 'chronographs', is to present "certain perspectival views of the world" (ibid.: 234). This was certainly the case with the museum display. Nevertheless, the 'perspective' suggested by these overall increases did not accentuate abundance in the same way as a tüm[en]-based scale does. It revealed a sense of increase that occurs across stalled growth patterns in horse numbers. In this respect, it is distinctly inferior to a tüm[en]-based system in which this special number can be taken up and scaled to trace the expansion of horse numbers in a crystal clear, unambiguous, and affectively powerful way.

\section{Conclusion}

In this article, I have drawn on Mongolian ethnography to interrogate how aspects of number make it amenable to being mobilized into ideologically powerful scales. I have done so by analyzing the intersection between two different social framings of number: number as endowed with a certain conceptual 
stability, and the fact that such numbers can be situated within scales that have a particular ideological force. This is not to say that an ideology of plenty in horses in Erdene emerges solely from the use of a tüm[en]-based scale of counting. Instead, it is to note that the use of such a scale both buttresses and contributes to the production and reproduction of such an ideology.

Attention to the relationship between number and scale is already well established in anthropology. To return to the literature cited at the beginning of this article, Marilyn Strathern ([1991] 2004) hinted at how the production of anthropological knowledge has quantitative scalar dimensions. This approach was made via her analysis of two main types of scaling: "domaining" and "magnification" (ibid.: xvi). These types of scaling, whose names are drawn from optical metaphors that sit within Strathern's broader vocabulary on scale (focus, magnitude, observation, myopia), "yield sets of internal measurements and hence coordinates along which the scale of phenomena may be changed" (ibid.). As Martin Holbraad and Morten Axel Pedersen (2017: 122) observe in relation to "quantitative scaling" in Strathern's writings, such an approach involves "switches in size, and corresponds to the conventional meaning of 'scale' as having to do with numerical measurement and size." Extrapolating from this point of view, one could regard scale in a more general sense as inherently incrementalized, that is to say, hypothetically divisible into units that allow scale itself to be made intelligible in quantitative terms.

But the ethnography from Erdene soum affords a different analytic perspective on the relationship between scale and number. It reveals how the emplacement of number within scales of measurement is more complex than one of conceptual encompassment, in which the relation between scale and number (in classical philosophical terminology) is the same as that between genus and species. Instead, tüm[en] is examined in its own terms as something with highly stable, qualitative-cum-quantitative attributes. Its ability to suggest quantitative size and qualitative abundance makes it ideal for enacting a scale (of livestock counting) designed to valorize an ideology of abundance in horses. It does so by referring to a pre-existing ideology of plenty while at the same time buttressing, supporting, and critically shaping how this ideology is experienced through the medium of a term that is powerful in its quantitative-cum-qualitative reach. By attending to how number is mobilized to produce scale, rather than the other way around, this article contributes to analytic exploration of the role of number in anthropological studies of scale. 


\section{Acknowledgments}

An early version of this article was presented at the American Center for Mongolian Studies in Ulaanbaatar, Mongolia, in September 2018. I thank the editor of Social Analysis and two anonymous reviewers for their thoughtful, stimulating, and helpful comments on this article. I also thank the following scholars for their comments on draft versions: Rebecca Empson, Elizabeth Fox, William Matthews, Erdene-Ochir Tumen-Ochir, and Mari Valdur. The PhD research on which this article is based was funded by the Economic and Social Research Council (grant number B102291G). This article was written during a Research Fellowship in Anthropology at University College London, funded by the European Research Council as part of the "Emerging Subjects" project (ERC-2013CoG, 615785). I wholeheartedly thank these organizations for their support.

Joseph Bristley is a Research Associate in Anthropology at the Mongolia and Inner Asia Studies Unit, University of Cambridge. He received a PhD in Anthropology from University College London in 2017 for a thesis examining economic aspects of animal husbandry in Mongolia. Aside from Inner Asian pastoralism, his academic interests include environmental anthropology, economic anthropology, and the anthropology of time. He has published in Inner Asia. E-mail: jb2329@cam.ac.uk

\section{Notes}

1. Celebrated for centuries, Mongolia's naadam became an important political festival during the country's socialist regime (1921-1990). Since 2003, it has been designated as Ulsyn Ikh Bayar Naadam, or Naadam State Great Festival, and commemorates historical events ranging from the People's Revolution of 1921 to the establishment of the first Khünüu state in the third century BC (Stolpe and Dulam 2017).

2. The English term 'myriad', which now suggests large numbers of things, once also meant 'ten thousand'-a word whose etymology was the classical Greek uvpios (murios) (Liddell and Scott 1889: 522). In Daoism, the Chinese term for ten thousand, 万 (wán), is used to describe a multiplicity of things that came into being at the beginning of the universe (Lao-Tzu 1993: 1). Tüm[en], of course, does not suggest a wide number of entities as does the Daoist wán, but it still connotes expansiveness.

3. In autumn 2014, an ikh nas (six-year-old plus) horse in Erdene soum could be expected to sell for between MNT (Mongolian Tugrik) 700,000 and 970,000. This price falls below that expected for a bullock (shar ükher) at up to MNT 
2,000,000 per head. Nevertheless, these mean prices do not reflect the incredibly high prices potentially payable for fast horses used in racing. During the same period of time, horsemeat (at a nominal price per kilogram, arrived by dividing the mean weight of an animal by its total unit price) could expect to sell for between MNT 4,500 and 6,000. Despite having khaluun (warm) qualities that make it a popular food during autumn and winter, its nominal price was less than expected for the same weight of beef (MNT 12,000 per kilogram).

4. The smallest bank note effectively now in circulation is MNT 10, although one such bank note can purchase practically nothing by itself. The largest denomination bank note in use today is valued at MNT 20,000.

5. Before their expulsion in the mid-1920s, the representatives of numerous Chinese trading houses (püüs) operated in Mongolia. They allowed herders and others to purchase goods (tea, cloth, sugar) on credit, to be repaid at a later date with livestock (Sanjdorj 1980). From the mid-1950s, livestock were transferred from private hands into collective ownership. This meant that collectives managed huge herds of state-owned flocks that had been previously owned by individual household heads.

6. Tüm[en] was originally used during the Middle Ages as a military unit nominally consisting of 10,000 soldiers.

7. I thank T. Erdene-Ochir for bringing this mantra to my attention.

8. In 1940, horse numbers stood at 19,565 head. Due to Mongolia's supporting the Soviet Union with livestock supplies during World War II, Erdene's horse numbers fell to 12,379 head by 1950 and did not come close to their approximate pre-war levels until 1970 (at 19,061 head). A fall between 1970 and 1980 (to 14,697 head) was followed by an upturn to 19,175 by 1990 . The source for these figures is Erdene's district museum.

\section{References}

Asian Development Bank. 2019. “Economic Indicators for Mongolia.” https:// www.adb.org/countries/mongolia/economy.

Bakhtin, M. M. 1981. "Forms of Time and of the Chronotope in the Novel: Notes toward a Historical Poetics.” In M. M. Bakhtin, The Dialogic Imagination: Four Essays, ed. Michael Holquist; trans. Caryl Emerson and Michael Holquist, 84-285. Austin: University of Texas Press.

Bawden, C. R. 1968. The Modern History of Mongolia. New York: Frederick A. Praeger.

Bazarragchaa, M. 2005. Mongol Khelnii Ögüülber Sudlal [Mongolian syntax]. Ulaanbaatar.

Bohannan, Paul. 1959. "The Impact of Money on an African Subsistence Economy." Journal of Economic History 19 (4): 491-503.

Bristley, Joseph. 2015. "Transformation and Multiplicity: Zoos and the Power to Absorb Spirits in Mongolia.” Inner Asia 17 (1): 31-51. 
Carr, E. Summerson, and Michael Lempert. 2016a. "Introduction: Pragmatics of Scale." In Carr and Lempert 2016b, 1-20.

Carr, E. Summerson, and Michael Lempert, eds. 2016b. Scale: Discourse and Dimensions of Social Life. Oakland: University of California Press.

Chabros, Krystyna. 1992. Beckoning Fortune: A Study of the Mongol Dalalya Ritual. Wiesbaden: Otto Harrassowitz.

Chingel, G., ed. 1990. Mongol Yos Zanshlyn Dund Tailbar Tol' [Medium encyclopedia of Mongolian traditions and customs]. Ulaanbaatar: 'Süülenkhüü' Khüükhdin Khevleliin Gazar.

Comaroff, Jean, and John Comaroff. 2003. "Ethnography on an Awkward Scale: Postcolonial Anthropology and the Violence of Abstraction.” Ethnography 4 (2): 149-179.

Crump, Thomas. 1990. The Anthropology of Numbers. Cambridge: Cambridge University Press.

Dulam, Sendenjavyn, and Jaroslav Vacek. (1983) 2013. A Mongolian Mythological Text. Ulaanbaatar: Bit Press.

Empson, Rebecca. 2011. Harnessing Fortune: Personhood, Memory, and Place in Mongolia. Oxford: Oxford University Press.

Evans-Pritchard, E. E. 1940. The Nuer: A Description of the Modes of Livelihood and Political Institutions of a Nilotic People. Oxford: Clarendon Press.

Firth, Raymond. (1953) 1964. "The Study of Values by Social Anthropologists." In Raymond Firth, Essays on Social Organization and Values, 206-224. London: Athlone Press.

Foucault, Michel. 1997. "Security, Territory, and Population.” In Michel Foucault, Ethics: Subjectivity and Truth, vol. 1, ed. Paul Rabinow, 67-72. New York: New Press.

Gal, Susan. 2016. "Scale-Making: Comparison and Perspective as Ideological Projects.” In Carr and Lempert 2016b, 91-111.

Gell, Alfred. 1992. The Anthropology of Time: Cultural Constructions of Temporal Maps and Images. Oxford: Berg.

Gellner, Ernest. 1978. “Notes towards a Theory of Ideology.” L'Homme 18 (3-4): 69-82.

Graeber, David. 2001. Toward an Anthropological Theory of Value: The False Coin of our Own Dreams. New York: Palgrave.

Griffin, Keith. 1995. "Economic Strategy During the Transition.” In Poverty and the Transition to a Market Economy in Mongolia, ed. Keith Griffin, 1-26. New York: St. Martin's Press.

Guyer, Jane I. 2004. Marginal Gains: Monetary Transactions in Atlantic Africa. Chicago: University of Chicago Press.

High, Mette M. 2017. Fear and Fortune: Spirit Worlds and Emerging Economies in the Mongolian Gold Rush. Ithaca, NY: Cornell University Press.

Holbraad, Martin, and Morten Axel Pedersen. 2017. The Ontological Turn: An Anthropological Exposition. Cambridge: Cambridge University Press.

Humphrey, Caroline. 1992. "The Moral Authority of the Past in Post-Socialist Mongolia.” Religion, State and Society 20 (3-4): 375-389. 
Humphrey, Caroline, and David Sneath. 1999. The End of Nomadism? Society, State and the Environment in Inner Asia. Durham, NC: Duke University Press. Irvine, Judith T. 2016. "Going Upscale: Scales and Scale-Climbing in Ideological Projects.” In Carr and Lempert 2016b, 213-232.

Lao-Tzu. 1993. Tao Te Ching. Trans. Stephen Addiss and Stanley Lombardo. Indianapolis, IN: Hackett Publishing.

Lenin, V. I. (1918) 1992. The State and Revolution. Trans. and ed. Robert Service. London: Penguin Books.

Liddell, H. G., and Robert Scott, eds. 1889. An Intermediate Greek-English Lexicon. Oxford: Oxford University Press.

Lienhardt, Godfrey. 1961. Divinity and Experience: The Religion of the Dinka. New York: Oxford University Press.

Malinowski, Bronislaw. (1922) 2010. Argonauts of the Western Pacific: An Account of Native Enterprise and Adventure in the Archipelagoes of Melanesian New Guinea. Oxford: Blackwell.

Marx, Karl, with Friedrich Engels. (1846) 1998. The German Ideology. Amherst, NY: Prometheus Books.

Mitchell, Timothy. 2002. Rule of Experts: Egypt, Techno-Politics, Modernity. Berkeley: University of California Press.

Mostaert, Antoine. (1941-1944) 2009. Dictionnaire Ordos [Ordos dictionary]. Monograph Series V. Ulaanbaatar: New Polygraph.

Ross, Sandy, Mario Schmidt, and Ville Koskinen. 2017. "Introduction: Overcoming the Quantity-Quality Divide in Economic Anthropology.” Social Analysis 61 (4): $1-16$.

Rossabi, Morris. 2005. Modern Mongolia: From Khans to Commissars to Capitalists. Berkeley: University of California Press.

Sahlins, Marshall. 1974. Stone Age Economics. London: Tavistock.

Sanjdorj, M. 1980. Manchu Chinese Colonial Rule in Northern Mongolia. Trans. Urgunge Onon. London: C. Hurst.

Sneath, David. 2012. "The 'Age of the Market' and the Regime of Debt: The Role of Credit in the Transformation of Pastoral Mongolia." Social Anthropology 20 (4): 458-473.

Stolpe, Ines, and Sendenjavyn Dulam. 2017. "Back to the Future: Mongolia's Festival Calendar Revisited.” In Mongolian Responses to Globalisation Processes, ed. Ines Stolpe, Judith Nordby, and Ulrike Gonzales, 187-222. Berlin: EB Verlag.

Strathern, Marilyn. (1991) 2004. Partial Connections. Updated ed. Walnut Creek, CA: AltaMira Press.

Strathern, Marilyn. 1995. The Relation: Issues in Complexity and Scale. Cambridge: Prickly Pear Press.

Sürenkhorloo, Darjaagiin. 2010. Minii Saikhan Nutag: Tü̈̈khen, temdeglel, dursamj. [My beautiful homeland: Historical notes and memories]. Ulaanbaatar: Soyombo Printing.

Tumurtogoo, Domii. 2018. An Etymological Dictionary of Mongolian Language. Ulaanbaatar: Mongolian Academy of Sciences 
Tsing, Anna L. 2012. "On Nonscalability: The Living World Is Not Amenable to Precision-Nested Scales." Common Knowledge 18 (3): 505-524.

Tsing, Anna L. 2015. The Mushroom at the End of the World: On the Possibility of Life in Capitalist Ruins. Princeton, NJ: Princeton University Press.

Verran, Helen. 2001. Science and an African Logic. Chicago: University of Chicago Press.

Virillio, Paul. (1977) 2006. Speed and Politics: An Essay on Dromology. Trans. Mark Polizzotti. Los Angeles: Semiotext(e).

Wastell, Sari. 2001. "Presuming Scale, Making Diversity: On the Mischiefs of Measurement and the Global: Local Metonym in Theories of Law and Culture." Critique of Anthropology 21 (2): 185-210. 